\section{ILLEGAL FISHING DI INDONESIA MENURUT UNDANG-UNDANG NOMOR 5 TAHUN 1983 TENTANG ZONA EKONOMI EKSKLUSIF INDONESIA $^{1}$}

Oleh: Adeleida M. B. Mandagie ${ }^{2}$

Tonny Rompis ${ }^{3}$

Thor Bangsaradja Sinaga ${ }^{4}$

\begin{abstract}
ABSTRAK
Tujuan dilakukannya penelitian ini adalah untuk mengetahui bagaimana penerapan UndangUndang Nomor 5 Tahun 1983 tentang Zona Ekonomi Eksklusif Indonesia, yang mengatur mengenai illegal fishing dan bagaimana upaya pemerintah dalam pemberantasan illegal fishing di Indonesia. Dengan menggunakan metode penelitian yuridis normatif,
\end{abstract} disimpulkan: 1. Penerapan Undang-Undang Nomor 5 Tahun 1983 tentang Zona Ekonomi Eksklusif Indonesia adalah jalur diluar dan berbatasan dengan laut wilayah Indonesia sebagaimana ditetapkan berdasarkan UndangUndang yang berlaku di perairan Indonesia yang meliputi dasar laut, tanah dibawahnya dan air diatasnya dengan batas terluar 200 mil laut diukur dari garis pangkal laut wilayah Indonesia. Dan dalam melakukan eksplorasi dan ekspoitasi sumber daya perikanan harus menaati ketentuan yang ditetapkan. Dalam Undang-Undang ini juga mengatur mengenai hak berdaulat, hak-hak lain dan yurisdiksi Zona Ekonomi Eksklusif Indonesia, aparatur penegak hukum yang berwenang dapat mengambil tindakan penegakan hukum sesuai dengan Undang-Undang nomor 8 tahun 1981 tentang KUHAP. 2. Upaya Pemerintah dalam memberantas illegal fishing yang terjadi di wilayah perairan Indonesia antara lain, melalui Vessel Monitoring System yang merupakan salah satu bagian pengawasan kapal yang berbasis satelit, mulai diterapkan di Indonesia sejak tahun 2003 dan terus dikembangkan. Laut Indonesia selama ini diawasi atau dikelola oleh setidaknya 7 kementerian atau lembaga. Pengawasan langsung melalui kapal patroli, baik yang bekerja sama dengan TNI AL, Polisi Air, dan TNI AU. Beberapa tahun terakhir

\footnotetext{
${ }^{1}$ Artikel Skripsi

${ }^{2}$ Mahasiswa pada Fakultas Hukum Unsrat, NIM. 16071101063

${ }^{3}$ Fakultas Hukum Unsrat, Magister IImu Hukum

${ }^{4}$ Fakultas Hukum Unsrat, Magister IImu Hukum
}

Pemerintah Indonesia diwakili oleh Menteri Kelautan dan Perikanan telah menenggelamkan kapal-kapal pelaku illegal fishing. Peneggelaman kapal ini merupakan salah satu upaya Pemerintah Indonesia untuk membuat jera para pelaku illegal fishing sehingga dapat memberantas illegal fishing di Indonesia, khususnya di Zona Ekonomi Eksklusif Indonesia. Kata kunci: Illegal Fishing, Di Indonesia, Zona Ekonomi Eksklusif Indonesia

\section{PENDAHULUAN}

\section{A. Latar Belakang Masalah}

Wilayah Zona Ekonomi Eksklusif Indonesia merupakan wilayah laut yang mempunyai potensi kekayaan yang terbesar bagi Bangsa Indonesia. Laut Indonesia memiliki nilai strategis dalam bidang politik, hukum, ekonomi, sosial budaya serta pertahanan dan keamanan. Kekayaan laut belum mampu dimanfaatkan secara optimal bagi kemajuan perekonomian bangsa. Demikian juga terkait keamanan laut, terutama yang berbatasan dengan negara tetangga. Kondisi laut yang berubah sehingga sulit menentukan batas wilayah laut menjadi alasan bagi para pelaku melakukan illegal fishing.

Oleh karena itu untuk menciptakan wilayah laut yang aman, lestari, serta menjaga dan memanfaatkan segala potensi besar yang dimiliki oleh laut Indonesia merupakan hal penting yang harus dilakukan oleh Pemerintah dan Masyarakat Indonesia. Pemerintah telah mengeluarkan berbagai jenis produk hukum dalam mengatur, melindungi serta melakukan penegakan hukum di wilayah Zona Ekonomi Eksklusif Indonesia (ZEEI). Undang-Undang nomor 5 tahun 1983 tentang Zona Ekonomi Eksklusif Indonesia serta produk-produk hukum terkait untuk melindungi wilayah ZEEI.

Undang-Undang Nomor 5 tahun 1983 tentang Zona Ekonomi Eksklusif Indonesia, yang disahkan pada tanggal 18 Oktober 1983, dibuat untuk mengatur, melindungi serta melakukan penegakan hukum di wilayah Zona Ekonomi Eksklusif Indonesia, serta sebagai landasan bagi pelaksanaan hak dan kewajiban-kewajiban Republik Indonesia di Zona Ekonomi Eksklusif Indonesia.

Penulis melihat bahwa akan sulit untuk menghentikan kejahatan ini jika tidak ada kerjasama dari semua pihak yang terkait. 
Sehingga berdasarkan masalah tersebut penulis tertarik untuk melakukan penelitian tentang illegal fishing yang terjadi di wilayah perairan Indonesia khususnya di zona ekonomi eksklusif Indonesia, serta peran pemerintah dalam memberantas kejahatan ini, dengan mengangkat judul "Illegal Fishing di Indonesia Menurut Undang-Undang Nomor 5 Tahun 1983 tentang Zona Ekonomi Eksklusif Indonesia".

\section{B. Rumusan Masalah}

1. Bagaimana penerapan Undang-Undang Nomor 5 Tahun 1983 tentang Zona Ekonomi Eksklusif Indonesia, yang mengatur mengenai illegal fishing?

2. Bagaimana upaya pemerintah dalam pemberantasan illegal fishing di Indonesia?

\section{Metode Penelitian}

Penelitian hukum normatif disebut juga penelitian doktrinal. Pada penelitian hukum jenis ini, acapkali hukum dikonsepkan sebagai apa yang tertulis dalam peraturan perundangundangan (law in books) atau hukum dikonsepkan sebagai kaidah atau norma yang merupakan patokan berperilaku manusia yang dianggap pantas. Oleh karena itu, pertama, sebagai sumber datanya hanyalah data sekunder, yang terdiri dari bahan hukum primer, dan bahan hukum sekunder atau data tersier. $^{5}$

\section{PEMBAHASAN}

\section{A. Penerapan Undang-Undang Nomor 5 Tahun 1983 Tentang Zona Ekonomi Eksklusif Indonesia}

Berdasarkan pasal 2 UU ZEEI, Zona Ekonomi Eksklusif Indonesia adalah jalur di luar dan berbatasan dengan laut wilayah Indonesia sebagaimana ditetapkan berdasarkan UndangUndang yang berlaku tentang perairan Indonesia yang meliputi dasar laut, tanah dibawahnya dan air di atasnya dengan batas terluar 200 (dua ratus) mil laut diukur dari garis pangkal laut wilayah Indonesia. Dalam pengaturan kewenangan yang terkait dengan daerah dan jenis sumber daya alam yang

\footnotetext{
${ }^{5}$ Amiruddin dan H. Zainal Asikin, Pengantar Metode Penelitian Hukum, PT Rajagrafindo Persada, Depok, 2018, hlm 118.
}

terdapat di dalamnya, dibedakan menjadi dua, yaitu bertalian dengan daerah dasar laut dan tanah dibawahnya dengan jenis sumber alam non hayati, maka ditundukan pada peraturan perundang-undangan Landasan Kontinen, sebaliknya kalau di luar daerah tersebut dan jenisnya merupakan sumber daya alam hayati, maka dilaksanakan menurut peraturan perundang-undangan Zona Ekonomi Eksklusif Indonesia. ${ }^{6}$

Dalam zona ekonomi eksklusif Indonesia, lebih lanjut diatur bahwa dalam melakukan eksplorasi dan eksploitasi sumber daya perikanan harus menaati ketentuan pengelolaan dan konservasi yang ditetapkan dengan perundang-undang nasional. Pengaturan demikian dimaksudkan untuk melindungi kepentingan-kepentingan negara pantai dalam rangka menopang pemanfaatan sumber daya perikanan di zona tersebut.

Konvensi Perserikatan Bangsa-Bangsa tentang Hukum Laut memberikan kepada Republik Indonesia sebagai negara pantai hak berdaulat untuk eksplorasi dan eksploitasi sumber daya alam yang terdapat di zona ekonomi eksklusif dan yurisdiksi yang berkaitan dengan pelaksanaan hak berdaulat tersebut. Selain daripada itu, Indonesia berkewajiban pula untuk menghormati hak-hak negara lain di zona ekonomi eksklusif antara lain kebebasan pelayaran dan penerbangan, serta pemasangan kabel dan pipa bawah laut di zona ekonomi eksklusif. ${ }^{7}$

Hak berdaulat Indonesia yang dimaksud dalam undang-undang ini tidak sama atau tidak dapat disamakan dengan kedaulatan penuh yang dimiliki dan dilaksanakan oleh Indonesia atas laut wilayah, perairan Nusantara dan perairan pedalaman Indonesia. Berdasarkan hal tersebut diatas maka sanksi-sanksi yang diancamdi Zona Ekonomi Eksklusif Indonesia berbeda dengan sanksi-sanksi yang diancam di perairan yang berada dibawah kedaulatan Republik Indonesia tersebut. Hak-hak lain berdasarkan hukum internasional adalah hak Republik Indonesia untuk melaksanakan penegakan hukum dan hot pursuit terhadap kapal-kapal asing yang melakukan pelanggaran atas ketentuan-ketentuan peraturan perundang-undangan Indonesia mengenai zona

\footnotetext{
${ }^{6}$ Ida Kurnia, op.cit, hlm 85

${ }^{7}$ Penjelasan Undang-Undang Nomor 5 Tahun 1983.
} 
ekonomi eksklusif. Kewajiban lainnya berdasarkan hukum internasional adalah kewajiban Republik Indonesia untuk menghormati hak-hak negara lain, misalnya kebebasan pelayaran dan penerbangan. ${ }^{8}$

Hot pursuit merupakan kewenangan yang dilakukan oleh negara pantai terhadap pelanggaran yang dilakukan oleh kapal asing didalam wilayah laut negara pantai, pengaturan mengenai hot persuit diatur dalam pasal 111 UNCLOS 1982. Hot pursuit yang artinya pengejaran terhadap kapal-kapal yang diduga melakukan tindak pidana di wilyah teritorial suatu negara.

Komitmen Indonesia terhadap pengelolaan dan sumber daya ikan yang terdapat di zona ekonomi eksklusif Indonesia dituangkan dalam Undang-Undang nomor 5 tahun 1983 melalui Pasal 5 yang berbunyi :

1. Dengan tidak mengurangi ketentuan Pasal 4 (ayat 2), barang siapa melakukan eksplorasi dan/atau ekspolitasi sumber daya alam atau kegiatan-kegiatan lainnya untuk eksplorasi dan/atau ekspolitasi ekonomis seperti pembangkitan tenaga dari air, arus dan angin di Zona Ekonomi Eksklusif Indonesia, harus berdasarkan izin dari Pemerintah Republik Indonesia atau berdasarkan persetujuan internasional dengan Pemerintah Republik Indonesia ada dilaksanakan menurut syarat-syarat perizinan atau persetujuan internasional.

2. Dengan tidak mengurangi ketentuan ayat (1), eksplorasi dan/atau ekspolitasi sumber daya hayati harus mentaati ketentuan tentang pengelolaan dan konservasi yang ditetapkan oleh Pemerintah Republik Indonesia.

3. Dengan tidak mengurangi ketentuan Pasal 4 ayat (2), eksplorasi dan eksploitasi suatu sumber daya alam hayati di daerah tertentu di Zona Ekonomi Eksklusif Indonesia oleh orang atau badan hukum atau Pemerintah Negara Asing dapat diizinkan jika jumlah tangkapan yang diperbolehkan oleh Pemerintah Republik Indonesia untuk jenis tersebut melebihi kemampuan Indonesia untuk memanfaatkannya.

\footnotetext{
${ }^{8}$ Penjelasan Undang-Undang Nomor 5 Tahun 1983, pasal 4 ayat 1.
}

Dalam rangka menunjang pembangunan yang berkelanjutan, UU ZEEI juga mengatur mengenai ketentuan-ketentuan penegakan hukum, yang terdapat dalam Bab VI UndangUndang nomor 5 tahun 1983 tentang Zona Ekonomi Eksklusif Indonesia sebagai berikut:

Pasal 13

Dalam rangka melaksanakan hak berdaulat, hak-hak lain, yurisdiksi dan kewajibankewajiban sebagaimana dimaksud dalam pasal 4 ayat (1), aparatur penegak hukum Republik Indonesia yang berwenang, dapat mengambil tindakan-tindakan penegakan hukum sesuai dengan Undang-Undang nomor 8 tahun 1981 tentang Kitab Undang-Undang Hukum Acara Pidana, dengan pengecualian sebagai berikut:

a. Penangkapan terhadap kapal dan/atau orang-orang yang diduga melakukan pelanggaran di Zona Ekonomi Eksklusif Indonesia meliputi tindakan penghentian kapal sampai dengan diserahkannya kapal dan/atau orang-orang tersebut dipelabuhan dimana perkara tersebut dapat di proses lebih lanjut;

b. Penyerahan kapal dan/atau orang-orang tersebut harus dilakukan secepat mungkin dan tidak boleh melebihi jangka waktu 7 (tujuh) hari, kecuali apabila terdapat keadaan force majeure;

c. Untuk kepentingan penahanan, tindak pidana yang diatur dalam pasal 16 dan pasal 17 termasuk dalam golongan tindak pidana sebagaimana dimaksud dalam pasal 21 ayat (4) huruf b Undang-Undang nomor 8 tahun 1981 tentang Kitab Undang-Undang Hukum Acara Pidana.

Pasal 14

1. Aparatur penegak hukum di bidang penyidikan di Zona Ekonomi Eksklusif Indonesia adalah Perwira Tentara Nasional Indonesia Angkatan Laut yang ditunjuk oleh Panglima Angkatan Bersenjata Republik Indonesia.

2. Penuntut umum adalah jaksa pada pengadilan negeri sebagaimana dimaksud dalam ayat (3).

3. Pengadilan yang berwenang mengadili pelanggaran terhadap ketentuan undang-undang ini adalah pengadilan negeri yang daerah hukumnya meliputi pelabuhan dimana dilakukan penahanan terhadap kapal dan/atau orang-orang 
sebagaimana dimaksud dalam pasal 13 huruf a.

Menurut data Dirjen Pengawasan Sumber Daya Kelautan dan Perikanan, sejak Januari hingga 11 April 2019 telah berhasil menangkap 38 kapal illegal, terdiri dari 15 Kapal Ikan Asing (KIA) Vietnam, 13 KIA Malaysia, dan 10 Kapal Ikan Indonesia (KII). Jumlah tersebut menambah total tangkapan kapal ikan illegal yang berhasil ditangkap oleh KKP sepanjang tahun 2014-2019 (April) yang mencapai angka 582 kapal. $^{9}$

Pemanfaatan sumber daya kelautan dan perikanan perlu dibarengi dengan pengawasan yang optimal untuk memastikan pelaku usaha kelautan dan perikanan mematuhi ketentuan peraturan perundang-undangan yang berlaku. Terlebih lagi beberapa wilayah perairan Indonesia, seperti Selat Malaka, Laut Natuna dan Laut Utara Sulawesi, merupakan wilayah yang cukup rawan terjadi kegiatan illegal fishing oleh kapal ikan asing. Sering terjadinya tindakan illegal fishing tidak terlepas dari peraturan yang mengatur sumber daya ikan di Zona Ekonomi Eksklusif Indonesia yang ada selama ini, dan pelaksanaan dalam pengaturannya, khususnya pengaturan tentang kesempatan yang diberikan kepada negara lain dalam rangka memanfaatkan sumber daya ikan di ZEE Indonesia, serta potensi sumber daya alam lain yang terkandung didalamnya.

Seperti yang tertulis dalam Penjelasan Undang-Undang Nomor 5 tahun 1983 tentang Zona Ekonomi Eksklusif Indonesia, Undangundang ini menetapkan ketentuan-ketentuan pokok saja sedangkan pelaksanaan lebih lanjut dari ketentuan Undang-Undang ini akan diatur dalam peraturan perundang-undangan lainnya.

\section{B. Upaya Pemerintah Dalam Pemberantasan Illegal Fishing}

Menurut Susi, illegal fishing di Indonesia sudah berlangsung lama, hingga merugikan negara maupun nelayan. ${ }^{10}$ Berbagai upaya telah dilakukan untuk menanggulangi illegal fishing

\footnotetext{
${ }^{9}$ https://kkp.go.id/djpsdkp/artikel/10030-kinerjapengawasan-kkp-sepanjang-triwulan-1-2019-tunjukkancapaian-positif, Direktorat Jendral Pengawasan Sumber Daya Kelautan dan Perikanan, Kinerja Pengawasan KKP Sepanjang Triwulan1/2019, diakses pada tanggal 20/04/20.

${ }^{10}$ Achmad Farid, Kisah, Perjuangan dan Inspirasi Susi Pudjiastuti, Checklist, Yogyakarta, 2018, hlm 139.
}

yang terjadi di wilayah perairan Indonesia, tetapi belum menimbulkan efek jera. Dari tahun ketahun kejahatan ini terus bertambah dan kerugian yang ditimbulkan semakin besar. Untuk menekan kejahatan ini, pemerintah telah melakukan beberapa upaya antara lain sebagai berikut:

\section{Vessel Monitoring System (VMS)}

Salah satu metode pengawasan terhadap operasional kapal-kapal perikanan adalah melalui VMS. Penerapan VMS telah menjadi kesepakatan internasional (FAO) bagi negaranegara yang mengelola perikanan laut. VMS mulai diterapkan di Indonesia pada tahun 2003 dan hingga sekarang sistem ini terus dikembangkan guna menekan tingkat kejahatan perikanan. VMS adalah salah satu bagian dari sistem pengawasan kapal yang berbasis satelit yang dalam implementasinya terdiri atas komponen yang merupakan subsistem di samping satelitnya sendiri sebagai wahana transformasi data dari kapal ke pusat pengendali. ${ }^{11}$ VMS adalah implementasi teknologi informasi yang merupakan salah satu bentuk pengawasan di bidang penangkapan dan/atau pengangkutan ikan, yang menggunakan peralatan pemantauan kapal perikanan yang telah ditentukan. Dalam rangka pelaksanaan sistem ini, di Jakarta telah dibangun Fishing Monitoring Center (FMC) di Kantor Pusat Kementerian Kelautan dan Perikanan. Implementasi VMS dilaksanakan melalui pemasangan transmitter pada kapalkapal penangkap ikan agar penggerakannya dapat dipantau melakukan operasi penangkapan (posisi kapal, kecepatan kapal, jalur lintasan atau tracking, dan waktu terjadinya kegiatan penangkapan ikan yang terindikasi melakukan pelanggaran). ${ }^{12}$

Sejalan dengan kebijakan Menteri Kelautan dan Perikanan, bahwa dalam penyelenggaraan VMS mulai tahun 2007 para pemilik kapal perikanan di atas $100 \mathrm{GT}$ (gross tonnage) harus memasang alat tersebut. Adapun untuk kapalkapal dibawah ukuran 30 GT telah dikembangkan VMS offline yang bertujuan untuk mengetahui pola operasi yang kapalkapal perikanan skala kecil serta daerah penangkapan yang digunakan. Transmitter untuk ukuran ini disediakan oleh pemerintah.

\footnotetext{
${ }^{11}$ Nunung Mahmudah, op.cit, hlm 123.

${ }^{12} \mathrm{lbid}, \mathrm{hlm} 141$.
} 
Hingga saat ini dari Provinsi Aceh hingga Papua telah memiliki alat komunikasi yang diharapkan dapat mendukung sistem kerja VMS dalam menangani illegal fishing. ${ }^{13}$

Keuntungan yang diperoleh dengan menggunakan VMS bagi pemerintah antara lain sebagai berikut:

1) Mengurangi kerugian negara dari illegal fishing.

2) Dapat melakukan pengendalian dalam pemanfaatan sumber daya kelautan dan perikanan.

3) Dapat memperoleh data dan informasi mengenai pemanfaatan sumber daya perikanan secara cepat dan akurat.

\section{Upaya Pengawasan di Perairan Indonesia}

Pengawasan di laut tidaklah mudah karena biaya operasional kapal pengawasan cukup besar dan untuk melakukan pengawasan di laut selalu terbentur pada biaya operasional yang sangat tinggi. Belum lagi kesulitan lain saat penangkapan ikan dilakukan malam hari sehingga saat pengawas tiba di lokasi sudah tidak menemukan bukti terjadinya pelanggaran. $^{14}$

Laut Indonesia selama ini diawasi atau dikelola oleh setidaknya 7 kementerian atau lembaga. Mulai dari Kemenko Maritim dan Investasi, Kemenhub, Kementerian Lingkungan Hidup dan Kehutanan, KKP, Kemenparekraf, TNI AL dan Badan Informasi Geospasial. Banyaknya pihak yang 'menguasai' itu tidak menutup kemungkinan bakal tumpang tindih regulasi. ${ }^{15}$

Dalam penyelenggarannya, upaya pengawasan di laut terkait beberapa aspek antara lain aspek teknis, operasional, anggaran dan yuridis. Yang dimaksud dengan aspek yuridis ditekankan pada faktor-faktor kewenangan, koordinasi dan aparat penegak hukum. Faktor-faktor tersebut mempunyai korelasi yang sangat erat dan merupakan kunci yang penting dalam pelaksanaan pengawasan dan penegakan hukum di laut.

\footnotetext{
${ }^{13} \mathrm{Ibid}, \mathrm{hlm} 124$.

${ }^{14}$ Marhaeni Ria Siombo, "Hukum Perikanan Nasional dan Internasional”, PT Gramedia Pustaka Utama, 2010, hlm 4.

${ }^{15}$ https://kumparan.com/kumparanbisnis/perketatpengamanan-laut-ri-7-lembaga-negara-teken-keria-sama1spD9xZxOfO/full, Perketat pengamanan laut RI 7 lembaga negara tekan kerja sama, diakses pada tanggal 20/04/20.
}

Lembaga yang diberi kewenangan untuk menegakkan hukum di wilayah laut, yaitu Badan Keamanan Laut (Bakamla). Badan keamanan laut merupakan lembaga pemerintah nonkementerian yang berkedudukan dibawah dan bertanggung jawab langsung ke Presiden melalui menteri yang mengkoordinasikannya. Tugas Bakamla ini adalah melakukan patroli keamanan dan keselamatan di wilayah perairan Indonesia. ${ }^{16}$

Kejelasan mengenai kewenangan hukum masing-masing instansi penting karena lingkup kegiatan dalam bentuk pelanggaran hukum yang terjadi di laut relatif luas dan beragam. Mengingat kemungkinan terjadinya tumpang tindih kewenangan yang dimiliki oleh instansi terkait, maka untuk menjamin agar penegakan hukum di Perairan Indonesia dapat telaksana secara efektif dan efisien faktor yang penting juga adalah koordinasi. Penanganannya secara terpadu melalui koordinasi pada tingkat nasional sangat diperlukan terutama dalam keadaan rawan tanpa menghilangkan kewenangan fungsional masing-masing instansi. ${ }^{17}$ Adapun pelaksanan peran dan tugas bidang keamanan laut dibebankan kepada TNI $A L$. TNI AL mengemban tugas sebagai penegak kedaulatan dan sekaligus penegak hukum di laut. $^{18}$

Melihat banyaknya instansi yang melaksanakan tugas dan fungsi di dalam penegakan hukum di laut dan pantai, maka pemerintah melakukan penataan pengamanan perairan dengan membentuk Badan Keamanan Laut atau yang lebih dikenal dengan nama Bakamla. Bakamla RI dibentuk berdasarkan Undang-Undang Nomor 32 Tahun 2014 tentang Kelautan, serta Peraturan Presiden nomor 178 tahun 2014 tentang Badan Keamanan Laut (Bakamla). Tujuan dari regulasi ini adalah untuk membentuk satu lembaga yang memiliki kewenangan multi-fungsi sebagai penegak hukum laut, pelaksana search and rescue di laut, pelindung lingkungan laut, pengamanan

\footnotetext{
${ }^{16}$ H. Salim HS, “Pengantar Hukum Sumber Daya Alam”, PT Rajagrafindo Persada, 2018, hlm 35.

17 lbid, hlm 37.

${ }^{18}$ Tri Sulistyaningtyas, Susanto dan Dicky R. Munaf, "Sinergitas Paradigma Lintas Sektor di Bidang Keamanan dan Keselamatan Laut", PT Gramedia Pustaka Utama, 2015, hlm 22.
} 
pelayaran, pelindung nelayan dan pelaksana fungsi bea da cukai secara efektif dan efisien. ${ }^{19}$

Bakamla mempunyai tugas untuk melakukan patroli keamanan dan keselamatan di wilayah perairan Indonesia dan wilayah yurisdiksi Indonesia. ${ }^{20}$

\section{Upaya Penegakan Hukum}

Dalam Buku Seminar Hukum Laut Kelima tahun 1990 dinyatakan bahwa dalam pengertian penegakan hukum tersirat adanya tuntutan kemampuan untuk memelihara dan mengawasi pentaatan ketentuan-ketentuan hukum tertentu baik nasional maupun internasional di perairan di dalam yurisdiksi nasional Indonesia dan perairan lainnya dalam rangka membela dan melindungi kepentingan nasional lainnya. Dengan demikian sepanjang intensitas ancaman dianggap mengganggu tertib dan kepentingan hukum, maka tindakan yang diambil dalam menghadapi ancaman tersebut berupa penegakan hukum. Lebih jauh lagi dinyatakan bahwa pengertian umum penegakan hukum diartikan sebagai suatu kegiatan negara/aparatnya berdasarkan kedaulatan negara dan atau berdasarkan ketentuan-ketentuan hukum internasional agar supaya peraturan hukum yang berlaku dilaut, baik hukum nasional maupun aturan hukum internasional dapat diindahkan atau ditaati oleh setiap orang dan/atau badan hukum dan negara sebagai subyek hukum. Dengan demikian dapat tercipta tertib hukum nasional dan tertib hukum internasional. ${ }^{21}$

Dalam kenyataannya, proses penegakan hukum memuncak pelaksanaannya oleh para pejabat penegak hukum. Kaitannya dengan pembicaraan di atas adalah bahwa peranan peraturan hukum cukup besar dalam hubungannya dengan pelaksanaan peraturan yang dilakukan oleh para penegak hukum. Dengan kata lain, bahwa keberhasilan atau kegagalan para penegak hukum dalam melaksanakan tugasnya sebetulnya sudah

\footnotetext{
${ }^{19}$ Untung Suropati, lan Montratama dan Yohanes Sulaiman, "Indonesia Inc. Peta Jalan Menuju Poros Maritim Dunia", PT Elex Media Kamputindo, 2018, hlm 93. ${ }^{20}$ Nunung Mahmudah, op.cit hlm 128.

${ }^{21}$ Laporan Penelitian tentang Penegakan Hukum di Perairan Indonesia dan zona tambahan, Badan Pembinaan Hukum Nasional, 2013, hlm 12, diakses pada tanggal 22/04/20.
}

dimulai sejak peraturan hukum yang harus dijalankan tersebut dibuat.

Adapun pengertian penegakan hukum di laut sebagimana yang diamanatkan kepada TNI AL, yaitu segala kegiatan yang dilaksankan oleh TNI AL dalam rangka menegakkan hukum dan menjaga keamanan laut. ${ }^{22}$ Penegakan hukum dilaut merupakan suatu tindakan yang diberikan oleh hukum yang berlaku dan berkaitan dengan yurisdiksi suatu negara. Adapun yurisdiksi merupakan kewenagan baik untuk menentukan ketentuan maupun untuk memaksanya, serta membutuhkan kemampuan untuk memelihara dan mengawasi pentaatan ketentuan hukum, baik nasional maupun internasional, baik dalam yurisdiksi perairan nasional maupun perairan lainnya seperti ZEE Indonesia. Dengan demikian penegakan hukum itu pada prinsipnya merupakan kelanjutan dari yurisdiksi yang dimiliki oleh suatu negara.

Secara umum penegakan hukum terhadap tindak pidana illegal fishing memiliki berbagai kendala. Dalam hal ini terkait aparat penegak hukum, kekurangan baik dari segi kuantitas dan kualitas aparat penegakan hukum akan sangat mempengaruhi efektivitas penegakan hukum di perairan Indonesia. Aparat penegak hukum baik dalam arti preventif maupun represif dalam menangani kasus-kasus illegal fishing, disamping jumlahnya amat terbatas kemampuannya juga masih terbatas. Kemudian fasilitas dan sarana untuk mencapai tujuan penegakan hukum di wilayah perairan Indonesia. Ketiadaan atau keterbatasan fasilitas dan sarana penunjang lainnya akan sangat mempengaruhi keberhasilan penegakan hukum. Fasilitas dan sarana dibutuhkan karena menangani kasus-kasus tersebut akan melibatkan berbagai peralatan teknologi canggih untuk kepentingan operasionalisasinya.

Dalam penanganan illegal fishing diperlukan peraturan perundang-undangan yang dapat dijadikan pedomoan dalam menindak para pelaku illegal fishing. Berdasarkan Konvensi UNCLOS 1982 yang kemudian telah di ratifikasi dengan Undang- Undang nomor 17 tahun 1985, kemudian Pemerintah Indonesia juga telah mengeluarkan Undang-Undang nomor 31 tahun 2004 tentang perikanan jo. UndangUndang nomor 45 tahun 2009. Hal ini bertujuan

${ }^{22} \mathrm{Ibid}, \mathrm{hlm} 116$. 
agar para pelaku illegal fishing dapat ditindak sesuai dengan aturan.

Pemerintah Indonesia membuat Undangundang nomor 31 tahun 2004 tentang perikanan jo. Undang-Undang nomor 45 tahun 2009 sesuai dengan ketentuan internasional dalam bidang perikanan dan mengakomodasi masalah illegal fishing serta mengimbangi perkembangan kemajuan teknologi yang berkembang saat ini. Dalam pelaksanaan penegakan hukum di laut undang-undang ini sangat penting dan strategis karena menyangkut kepastian hukum dalam sektor perikanan. Upaya penegakan hukum tidak bisa lepas dari 4 hal yaitu sebagai berikut: ${ }^{23}$

a. Peraturan Perundang-undangan yang menjadi dasar hukum.

b. Sarana dan prasarana yang menjadi alat untuk menegakan hukum.

c. Sumber daya manusia yang menjadi pelaku penegakan hukum.

d. Budaya hukum yang berkembang di masyarakat.

Keempat pilar penegakan hukum tersebut harus dapat menopang secara keseluruhannya sehingga tidak terjadi ketimpangan dalam pelaksanaan penegakan hukum dan dapat berjalan dengan baik dan sesuai dengan aturan yang ada secara optimal.

Joko Widodo adalah Presiden yang terpilih pada Tahun 2014. Dalam pidato pelantikannya sebagai presiden, Joko Widodo menekankan politik luar negeri Indonesia bersandar pada maritim atau yang kemudian dikenal sebagai Poros Maritim Dunia. ${ }^{24}$ Salah satu agenda strategis yang disampaikan dalam pidato tersebut adalah mengembalikan Indonesia sebagai negara maritim dimana samudra, laut, selat, dan teluk sebagai masa depan peradaban Indonesia, "Untuk membangun Indonesia menjadi negara besar, negara kuat, negara makmur, negara damai, Indonesia harus memiliki jiwa Cakrawati Samudra; jiwa pelaut yang berani mengarungi gelombang dan hempasan ombak yang menggulung". ${ }^{25}$

Sepanjang empat tahun terakhir, Pemerintah Indonesia yang diwakili oleh Menteri Kelautan dan Perikanan, Susi

\footnotetext{
${ }^{23}$ Ibid, hlm 132.

${ }^{24}$ Agus Haryanto, dan Isman Pasha, "Diplomasi Indonesia Realitas dan Prospek", Pustaka IImu, 2016, hIm 260.

${ }^{25} \mathrm{lbid}, \mathrm{hlm} 261$.
}

Pudjiastuti telah menenggelamkan kapal-kapal pelaku illegal fishing. Jika merujuk pada data Kementerian Kelautan dan Perikanan sampai dengan tahun 2018, tercatat sebanyak 488 unit kapal milik pencuri ikan yang tela ditenggelamkan. Pemberantasan illegal fishing menjadi prestasi luar biasa yang telah dicapai Pemerintah Jokowi-JK selama 2015-2018. ${ }^{26}$

TNI AL sebagai komponen utama pertahanan di laut, mengemban tugas dan tanggung jawab untuk menegakkan kedaulatan negara di laut dan melindungi kepentingan nasional dilaut bersama-sama dengan komponen kekuatan pertahanan nasional lainnya. Untuk itu dibutuhkan kekuatan yang memadai, baik jumlah maupun kualitasnya sehingga mampu mengamankan potensi laut untuk kepentingan bangsa serta mencegah pemanfaatan potensi laut oleh bangsa lain yang merugikan kepentingan bangsa Indonesia.

\section{PENUTUP}

\section{A. Kesimpulan}

1. Penerapan Undang-Undang Nomor 5 Tahun 1983 tentang Zona Ekonomi Eksklusif Indonesia adalah jalur diluar dan berbatasan dengan laut wilayah Indonesia sebagaimana ditetapkan berdasarkan Undang-Undang yang berlaku di perairan Indonesia yang meliputi dasar laut, tanah dibawahnya dan air diatasnya dengan batas terluar 200 mil laut diukur dari garis pangkal laut wilayah Indonesia. Dan dalam melakukan eksplorasi dan ekspoitasi sumber daya perikanan harus menaati ketentuan yang ditetapkan. Dalam Undang-Undang ini juga mengatur mengenai hak berdaulat, hak-hak lain dan yurisdiksi Zona Ekonomi Eksklusif Indonesia, aparatur penegak hukum yang berwenang dapat mengambil tindakan penegakan hukum sesuai dengan Undang-Undang nomor 8 tahun 1981 tentang KUHAP.

2. Upaya Pemerintah dalam memberantas illegal fishing yang terjadi di wilayah perairan Indonesia antara lain, melalui Vessel Monitoring System yang merupakan salah satu bagian

\footnotetext{
26 "Sanksi pelaku illegal fishing dinilai terlalu ringan", https://kabar24.bisnis.com/read/20190321/16/902959/sa nksi-pelaku-illegal-fishing-dinilai-terlalu-ringan
} 
pengawasan kapal yang berbasis satelit, mulai diterapkan di Indonesia sejak tahun 2003 dan terus dikembangkan. Laut Indonesia selama ini diawasi atau dikelola oleh setidaknya 7 kementerian atau lembaga. Pengawasan langsung melalui kapal patroli, baik yang bekerja sama dengan TNI AL, Polisi Air, dan TNI AU. Beberapa tahun terakhir Pemerintah Indonesia diwakili oleh Menteri Kelautan dan Perikanan telah menenggelamkan kapal-kapal pelaku illegal fishing. Peneggelaman kapal ini merupakan salah satu upaya Pemerintah Indonesia untuk membuat jera para pelaku illegal fishing sehingga dapat memberantas illegal fishing di Indonesia, khususnya di Zona Ekonomi Eksklusif Indonesia.

\section{B. Saran}

1. Perlu adanya perundang-undangan baru yang mengatur secara keseluruhan mengenai illegal fishing guna mecegah tumpang tindihnya peraturan, demi tercapainya kepastian hukum dalam melindungi wilayah ZEE Indonesia dari para pelaku kejahatan tersebut dan sanksi yang diberikan dapat membuat jera para pelaku. Serta mengatur juga mengenai tugas dan kewenagan aparat penegak hukum serta garis koordinasi yang jelas antar instansi terkait.

2. Pemerintah Indonesia harus menyediakan sarana prasarana yang dapat mendukung pengawasan dan penegakan hukum di wilayah Perairan Indonesia, Serta mengadakan sosialisasi dan penyuluhan bagi masyarakat untuk mengetahui mengenai illegal fishing.

\section{DAFTAR PUSTAKA}

BUKU

Amiruddin dan H. Zainal Asikin. 2018. Pengantar Metode Penelitian Hukum. PT Rajagrafindo Persada.

Farid Achmad. 2018. Kisah, Perjuangan dan Inspirasi Susi Pudjiastuti. Checklist.

Haryanto, Agus dan Isman Pasha. 2016. Diplomasi Indonesia Realitas dan Prospek. Pustaka IImu.

Kurnia, Ida. 2018. Aspek Nasional dan Internasional Pemanfaatan Surplus
Perikanan di Zona Ekonomi Eksklusif Indonesia. Sinar Grafika. Jakarat.

Mahmudah, Nunung. 2015. Illegal Fishing: Pertanggungjawaban Pidana Korporasi di Wilayah Perairan Indonesia. Sinar Grafika. Jakarta.

HS, H Salim. 2018. Pengantar Hukum Sumber Daya Alam. PT Rajagrafindo Persada.

Siombo Mahaeni Ria Siombo. 2010. Hukum Perikanan Nasional dan Internasional. PT Gramedia Pustaka Utama.

Sodik, Dikdik Mohamad. 2016. Hukum Laut Internasional dan Pengaturannya di Indonesia, Cetakan Ketiga (Edisin Revisi). PT Refika Aditama. Bandung.

Sulistyaningtyas Tri, Susanto dan Dicky R. Munaf. 2015. Sinergitas Paradigma Lintas Sektor di Bidang Keamanan dan Keselamatan Laut. PT Gramedia Pustaka Utama.

Suropati Untung, Ian Montratama dan Yohanes Sulaiman. 2018. Indonesia Inc. Peta Jalan Menuju Poros Maritim Dunia. PT Elex Media Kamputindo.

\section{PERUNDANG-UNDANGAN}

Undang-Undang Nomor 5 Tahun 1983 Tentang Zona Ekonomi Eksklusif Indonesia.

Undang -Undang Nomor 8 Tahun 1981 Tentang Hukum Acara Pidana (KUHAP)

Undang-Undang Nomor 7 Tahun 1985 Tentang Pengesahan United Nations Convention on The Law of The Sea (UNCLOS).

Undang-Undang Nomor 31 Tahun 2004 Tentang Perikanan.

Undang-Undang Nomor 45 Tahun 2009 Tentang Perubahan atas Undangundang Nomor 31 Tahun 2004 Tentang Perikanan.

Undang-Undang Nomor 32 Tahun 2014 Tentang Kelautan.

Peraturan Presiden Nomor 178 Tahun 2014 Tentang Badan Keamanan Laut

JURNAL

Endiyono Raharjo dan Rio Saputra, "Illicit Enrichment dalam Penegakan Hukum Pengambilan Ikan Secara Tidak Sah (Illegal Fishing) di Wilayah Perairan Indonesia, Jurnal Hukum Internasional, Volume 25 Nomor 1 Maret 2017Agustus 2017, Program Magister IImu 
Hukum, Universitas Muhamadiyah, Malang.

"Perlindungan Hukum Zona Ekonomi Eksklusif terhadap Eksistensi Indonesia sebagai Negara Maritim" Aditya Nugraha dan Irman, Oktober 2014, http://law.umrah.ac.id/wpcontent/uploads/2015/01/JURNALSELAT-3-Irman.pdf diunduh tanggal 10/03/2020.

"Laporan Penelitian tentang Penegakan Hukum di Perairan Indonesia dan Zona Tambahan", Badan Pembinaan Hukum Nasional, 2013, http://www.bphn.go.id/data/document s/penegakan hk diperairan indonesia dan zona tambahan.pdf diunduh tanggal 22/04/2020.

"Penelitian Hukum tentang Mekanisme Penyelesaian Konflik antar Negara", Ulang Mangun Sosiawan, https://www.bphn.go.id/data/documen ts/mekanisme penyelesaian konflik an tar negara dlm pengolahan sd kelaut an.pdf diakses pada tanggal 22/04/2020.

"Gambaran Umum Illegal Fishing di Indonesia, http://repository.uinsuska.ac.id/7026/3/Bab\%201l\%20.pdf diakses pada tanggal 09/03/2020

"Pengaturan Sumber Daya Perikanan di Zona Ekonomi Eksklusif Indonesia", https://jurnal.ugm.ac.id/jmh/article/vie $\mathrm{w} / 16040 / 10586$ diakses pada tanggal $10 / 03 / 2020$

"Ketentuan Zona Ekonomi Eksklusif dan Landas Kontinen, Illegal Fishing dan Lintas Pelayaran Kapal Perang dalam Hukum Laut Internasional", http://repository.umy.ac.id/bitstream/h andle/123456789/11747/F.\%20BAB\%20 II.pdf?sequence $=6 \&$ isAllowed $=y$ diakses pada tanggal 10/03/2020

\section{WEBSITE}

Anonymous, Ancaman Illegal Fishing terhadap Kedaulatan Negara, https://www.kompasiana.com/tatamar a/5c8aec613ba7f75ala5ea4b2/illegalfishing?page=all

Direktorat Jenderal Pengawasan Sumber Daya Kelautan dan Perikanan, Kinerja
Pengawasan KKP Sepanjang Triwulan 1/2019, http://kkp.go.id.djpsdkp/artikel/10030kinerja-pengawasan-kkp-sepanjangtriwulan-1-2019-tunjukkan-capaianpositif

Fernandez Noviarizal, Sanksi Pelaku Illegal Fishing Dinilai Terlalu Ringan, https://kabar24.bisnis.com/read/20190 321/16/902959/sanksi-pelaku-illegalfishing-dinilai-terlalu-ringan

Rahayu, Isna Rifka Sri, Kasus Illegal Fishing, Menteri Susi Beberkan Wilayah Sulut Terbanyak, https://www.inews.id/finance/makro/k asus-illegal-fishing-menteri-susibeberkan-wilayah-sulut-terbanyak

Ristianto, Christoforus, Illegal Fishing di Laut Sulawesi, 3 Kapal dan 12 Awak Asal Filipina Ditangkap, https://nasional.kompas.com/read/201 9/08/22/18352371/illegal-fishing-dilaut-sulawesi-3-kapal-dan-12-awak-asalfilipina-ditangkap

Saputra, Joshua, Illegal Fishing dalam Aspek Hukum Internasional, https://kumparan.com/joshuasaputra/illegal-fishing-dalam-aspekhukum-internasional

Solagracia, Maylisda Frisca Elenor, Natuna Surganya Perairan RI, Ini Daftar Kapal Illegal Fishing yang Pernah Ditenggelamkan, https://economy.okezone.com/read/20 20/01/09/320/2151054/natunasurganya-perairan-ri-ini-daftar-kapalillegal-fishing-yang-pernahditenggelamkan.

Ulya, Definisi dan Perkembangan Illegal Fishing, https://ulyadays.com/definisiperkembangan-illegal-fishing/ 